\title{
Current Situation Research of Western Culture Teaching Qiuna Du
}

\author{
XingTai University, Xingtai, 054001, China
}

\author{
Keywords: Western culture, Teaching, Current situation
}

\begin{abstract}
Society plays great hope on the talents from universities and hopes they can be geared to international standards, know foreign historical civilization and cultural deposits. So, western culture teaching is faced with giant challenges. At present, western culture course of each university has certain defects, and teaching status is very severe. This paper will study and discuss western culture teaching, and explore teaching status and the method to improve teaching level so as to boost western culture quality of university students.
\end{abstract}

\section{Introduction}

With economic globalization, cultural exchange also develops to internationalization. Western cultural deposits and humanistic thought influence cognition of Chinese people to some extent. As an eastern country, we should actively know western culture, western social contact mode and development status of western society. Thus, many universities have set up western culture courses in order to make contemporary university students fully know western culture and really achieve cultural fusion. However, since teaching resources are weak in universities, and teaching plan. Course setting and teaching modes have some shortcomings, western culture teaching have some defects. Thus, university managers and teachers need to continuously explore new countermeasures to improve in order to let students learn western culture and achieve cultural fusion.

\section{Necessity of learning western culture}

The widest mode for Chinese students to contact western culture is to learn English. Students have contacted English culture since their childhood. Meanwhile, China attaches importance to students' ability to master English, so many English-related examinations are set up to judge their English mastery level. Qualification certificates of these exanimations also become "a threshold" of studying and working. In 1970s, Soviet leader Stalin proposed language study should be pure, like learning to drive[1]. Hence, Chinese students generally neglect western culture and consider English is a part of their academic performance and also language knowledge in need of continuously reciting and remembering. This completely distorts the original intention of English teaching. In such case, students can only learn the knowledge and skills required by examinations, but cannot master the essence of English exchange. Thus, their listening and speaking ability is poor. When students exchange with westerns, language is boring and has no practical meaning. Meanwhile, students fail to grasp well western culture and even ask foreigners the taboo questions. Foreigners cannot forgive such mistake. Usually, Chinese English exchange is of "Chinese style". English narrative order is sorted according to Chinese grammar sequence. Foreigners can accept grammar mistake, but cannot accept social language mistake ${ }^{[2]}$.

In conclusion, pure English knowledge teaching in universities cannot help students improve. University students need to know western social culture, language art and relevant cultural background in order to comprehensively cultivate their comprehensive quality and achieve integrated development of listening, speaking, reading, writing and translation. 


\section{Current situation of western culture teaching in universities}

\section{Teaching force of western culture course is weak}

Western culture course in universities mainly aims at students of English major. This course has high requirements for teachers. Since this course oriented to English majors, firstly, teachers need to own favorable English foundation and can speak English fluently; secondly, development history of western countries is complex and involved a wide range of fields. Besides, the time space is quite long. These are an ordeal for teachers' knowledge area. Western culture development experienced renaissance, industrial age and realism thought. Western culture teachers need to own basic philosophical thought, historic culture quality and literature knowledge. In addition, they also need to own certain art feelings. In this way, teachers can fuse the development history of western romanticism and teach students comprehensive and contagious western culture knowledge.

The above qualities are required by teachers of western culture course. In terms of teaching method, teachers are faced with Chinese students and should know university students can master most Chinese cultural knowledge background. Hence, when teaching western culture, teachers need to fully combine eastern and western cultures to avoid cultural shock. Teachers should grasp certain teaching methods, utilize students' acquaintance with eastern culture to find out the correct entry point from eastern and western cultures, help them utilize eastern culture to better master western culture and fuse the two so as to facilitate university students overall master western language and culture and achieve cultural fusion[3].

In conclusion, western culture teachers need to possess very high cultural literacy and master feasible teaching methods in order to make western culture teaching reach the ideal teaching state. At present, in the face of such teaching bottleneck, many teachers repel to teach western culture course. Thus, western culture course is taught by some young teachers in some universities. Most of such teachers are young teachers just graduating from universities. They lack teaching experience and cannot master such all-round skills. Thus, western culture teaching falls behind, and students cannot really grasp the essence of western culture.

\section{Course setting is inappropriate and students pay no attention to western culture course}

\section{Students pay no attention to western culture course}

In modern education, evaluation mode is the examination. Scores are used to reflect students' learning results. Teachers, parents and even students pay more attention to academic performance. So, western culture course is not essential for university students who attach importance to scores. Students attend western culture course for the purpose of discipline scores.

Western culture is difficult for beginners, so students are not interest in it

For beginner, it is hard for them to master western culture knowledge, because western development history is complex an abstract. Besides, western religion, reform and activity are relatively stiff for university students, and they cannot be close to western historical development. For them, western culture is remote and mysterious ${ }^{[4]}$. Meanwhile, the learning process is tedious. Thus, it is difficult for them grasp the knowledge. All these cause they are not interested in this course.

Students fear disciplines with complex knowledge contents and do not want to confront the result that they harvest little though they spend much energy. Such phenomenon results in the lack of interest in western culture course. Hence, university students can only master English foundation, cope with English examination in learning western culture, but the fluent exchange with westerners stands still.

The time for western culture course is insufficient, and course setting is improper

The time of western culture course is insufficient, and the course just lasts for one semester. The course is taught in the form of comprehensive and large class, and the number of students is large. Thus, students will consider this course is not important and they may skip this class. Such course setting makes students pay insufficient attention to western culture course.

Such situation is greatly related to course setting and teaching program of universities. The time of western culture course is insufficient, and teachers' teaching mode is irrational. All these cause 
students lose interest in western culture course. In this way, the objective of cultural exchange cannot be realized.

\section{Corresponding countermeasures for problems existing in western culture teaching}

\section{Teachers need to make classroom teaching mode innovative}

\section{Regard students as the subject and make them give play to abilities autonomously}

To make western culture teaching play its due role, university managers and teachers need to continuously create teaching methods and change to modern student-centered teaching from traditional teacher-centered teaching. University students have been tired of traditional teaching method. Teachers' teaching has almost no touch to students. So, teachers need to give students space in teaching process and mobilize their enthusiasm. For example, teachers may let students autonomously complete teaching work. Teachers give the teaching program to students, and they independently choose teaching method. But, students are required to explain clearly and the contents should have pedagogical meaning. Such mode can make students give play to their potential, promote them to know the knowledge learned and cultivate their innovative thinking and innovation ability.

Teach through lively activities and add classroom interestingness

Teachers should play a leading role in classroom. The development history of western culture needs to be taught to students by teachers so that students can construct history and culture knowledge frame and era features in their brain. In this basis, teachers should distinguish the concepts of "culture history" and "history" and make students cognize the differences, or else some students consider historical knowledge lacks interest all the time and are unwilling to study. So, when teachers teach the history of western culture, teachers should add classroom interestingness, teach through lively activities, attract students' attention, make them concentrate on knowledge content and absorb knowledge with interest.

Teachers should carry out contrastive teaching and promote students to comprehend and remember

When teaching western culture, teachers should combine eastern culture, because comparative teaching may be more easily comprehended and absorbed by students and help students remember. For instance, in Chinese traditional culture, human nature is good at birth, while human nature is hideous in western culture ${ }^{[5]}$. If people are born with painful cry, this indicates the life will be pitiful and hard. If people want to alleviate the sin, they have to be good people and do good things continuously. Only in this way, people can enter the paradise after they die. If the sin is not eliminated, people will go to the hell. Through such example, students can accept, understand and compare eastern and western cultures, cognize cultural differences and know the connotation of western culture.

\section{Teachers need to add auxiliary tools for western culture classroom}

Teachers need to adopt more diversified teaching mode for western culture classroom. Apart from traditional theoretical knowledge, teachers need to create different assisted teaching modes to make students more interested in the knowledge. Teachers may properly present more visual enjoyment to students in infectious culture teaching so that they will not the content is too stiff to accept. Some students consider they need to master examination skills and contents in modern examinations, so they are not interested in the contents taught by teachers. Thus, teachers need to apply visual and auditory sensory stimulation to drive students to enter culture situation, place them in the situation, positively face western culture learning and better absorb knowledge.

Teachers may carefully choose films containing western culture to play in classroom or apply images and pictures. For example, teachers may play Gentlemen Prefer Blondes. The heroine Marilyn Monroe is deeply loved. She sang in the film that, "diamond is the best friend of women". Maybe some consider Monroe is material and has no thought. But, university students may cognize Monroe is just a representative of western women. They do not cover their ideas or ingratiate others. 
They live truly and willfully. Students can know western culture, westerners' thought and behaviors through watching the film.

Teachers can help students visually feel westerners' social contact mode through sensory stimulation of films. To know features of western culture, students will be immersed in film plot, feel westerners' enthusiasm and cultural orientation with film development and music charm, approach western culture more practically and then know English charm. In this way, they will on longer learn English grammar mechanically, but combine culture and knowledge. This contributes to students to understand and better teaching culture knowledge for future constructors and successors.

\section{Conclusion}

In general, with economic globalization development, all sectors of society pay more and more attention to comprehensive quality of university students. Government agency, enterprise and public institutions yearn for inter-disciplinary talents. Currently, Chinese universities reform English teaching and regard cultivation of high-quality language talents as the objective. However, whether does future construction needs the talents who only own language certificates and cannot communicate with foreigners fluently? This deserves thinking. Knowledge mastery should be accompanied with culture understanding. The two supplement each other. Thus, western culture teaching should arouse high attention of universities and teachers. Universities should improve western culture course setting, create teaching methods, enhance teaching staff construction and make university students learn richer and more meticulous cultural knowledge. University students are future protagonists for future social development, so universities have heavy tasks to culture them. To achieve teaching objectives, it is necessary to continuously improve and perfect existing education system.

\section{References}

[1] Yang lei, Application of case study to teach History of Western Economic Thought [J]. Value Engineering, 2012,31(2):240-241.

[2] Zhu Hong, Exploration of reform of History of Western Philosophy [J]. China Education Innovation Herald, 2013(35):72.

[3] Wang Yong, Original works reading method in teaching History of Western Philosophy [J]. Tibet Education, 2013(12):37-39.

[4] Lv Sha, Construction and practice of bilingual education mode for Western Financial Accounting [J]. Finance \& Banking, 2013(6):91-95.

[5] Huang Fujie, Application of case study in western economics teaching [J]. Time Education, 2015(1):181-182. 